\title{
A Brief Inquiry into the Origins of St. Elmo, California - Laura Kalpakian
}

IN THE BEGINNING WAS THE PASS. As though God's massive knuckle curled up at the white desert, bore down and scraped its way up the foothills, the track rises high into the mountains and from there, careens downhill, a long natural pass, Jesuit Pass, spilling into a sea of sagebrush. The pass might even have reached the Pacific, except God seemed to lose interest in it, in the St. Elmo valley for that matter. Of course He did. If His aesthetic attention had not so clearly been called elsewhere in California, surely God would have carved out a genuine riverbed here, instead of the broad invisible channel, locally known as Dogsback Ditch, which floods, cruelly, every decade or so. No, face it, instead of a real river, God's forefinger punched holes in the earth's crust, artesian wells, like the St. Elmo valley was just a geological pie and the steam needed to escape. It's certainly true that beneath the earth's crust, this unstable pie continues to cook in the thermal fires, the bubble and boil resulting in frequent earthquakes. Grand quakes send people rushing into the street or crouching under tables, clutching their robes and children. But more often, the quakes are ticklers. That's what the locals call them, not simply for their having jiggled passions long dormant in the earth, but stirring other, long dormant longings, rousing long dormant spouses, lying in dry connubial beds. Many's the St. Elmo child who owes his life to an aftershock.

But one day, they say, the Big One will come. The fires inside will erupt, explode along the San Andreas fault. This fault is one of the staples of imagery in the work of California poets. They wax on as though the fault line reflects the flawed thread of human nature. Or, for some, the fault functions as a retribution pageant, Cecil B. DeMillian in scope, that would otherwise be too corny for words. Here, in St. Elmo, it's less cosmic. The city has the dubious honor of sitting squarely atop the San Andreas fault and when the Big One comes, everything west of Jesuit Pass will split, rip, tear off and-with the rest of Western California-become its own island republic. O say can you see the breakers crash and foam on the St. Elmo foothills? The long coppery ropes of seaweed lapping obscenely in the mouth of Jesuit Pass? 
If that Big One comes to pass, then the story of Jesuit Pass will not seem so mad. People won't ask: what was a crazy Jesuit doing here in the first place? Perhaps then, as now, California's inland reaches provided a sort of open-air lunatic asylum (placid, flaccid, lots of climate, no weather) where indifference passes for tolerance. But there were only Indians here when this valley was named. And why would a valley this far inland be named for St. Elmo's fire, a phenomenon associated with sailors and storms at sea, balls of green fire streaking across the heavens, striking ships, masts and bowsprits? St. Elmo, California is - was then, anyway -a sea of sagebrush, rabbitbrush, tough grasses, cottonwood, mesquite, an ocean of wind and light. Nonetheless, the story is that a shipwrecked Jesuit woke on this valley floor, that he built a tiny chapel of thanksgiving to the patron saint of sailors, named the pass and valley and moved on. From time to time and in various places, people claim to have found the remains of this chapel. That people believe there even are remains testifies that the Jesuit's story (while it cannot be held unmelting in history's crucible) has nevertheless accumulated a furry mantle of truth, the sort of thick, obscuring dust that crusts those bits of bone and hair in jeweled reliquaries, dust that decently veils what would otherwise be merely dismal or repulsive.

Anyway, more likely it would have been a Franciscan and not a Jesuit. Franciscan padres accompanied the armies of Spain into California - yoking together Crown and Cowl along the axis of the spear, the musket, and the whip, establishing the mission system, converting the Indians, giving them, for their pains, Christian burials when they died under the spear, the musket, and the whip. The Jesuits were not a presence in early California. The Jesuits were active elsewere in North America where they died really grim deaths, rivaling those of early Christian martyrs. After their deaths at the hands of the Iroquois (and other tribes of exquisite torturers, Indians whose relish for unthinkable pain was unexcelled) Jesuit fathers like St. Jean de Brebeuf and others were canonized, the church acknowledging that their faith had been tested beyond mere human endurance, as they were staked out and disemboweled before their own eyes.

The Indian tribes of greater St. Elmo, by contrast, had no such sophistication. They squatted under cottonwoods, in the shade of rocks, hunkered in winter under thatched-brush shelters. They poked and scrabbled for food, caught jackrabbits, held them by their ears and clubbed their brains out on rocks, cooked them on open fires. These Indians wove baskets 
of surpassing beauty, but by Iroquois standards, there was not a warrior amongst them. After the Spanish arrived this far inland, the Indians became notorious horsethieves, their tribal knowledge of the pass and its many rivulet-like canyons contributing to their success. However, it's dubious the Iroquois would have even then considered them warriors, though they did harass, in turn, the Spanish military, the missions, the Mexican rancheros, American wagon trains, freight convoys and assorted other travelers. They vanished with their livestock, occasionally taking their women, sometimes taking their lives, but leaving their bowels intact.

By 1866 the Indians of the greater St. Elmo area had been stashed on reservations scattered throughout the county's most uninviting reaches. St. Elmo's first historian, Herschel Petrey (1859-1928) tirelessly visited these reservations in the course of his research. He was, however, a historian and not at all an anthropologist and alas, gave little thought or inquiry to the Indians' lives before the Spanish came. The Spanish brought into California the whole notion of recorded history and this was the only sort that Herschel Petrey truly understood or venerated. So the questions he asked of the Indians elicited little more than the memoirs of horsethieves. Still, his book, History, Heritage and Legacy of St. Elmo (1916) is the first of its kind, a landmark and a collector's item.

The volume's slightly redundant title reflects Mr. Petrey's grand conception of his work; at the same time it suggests a fundamental confusion of intent. This book absorbed Herschel Petrey's life, his fortune, his sacred honor and his entire family. It was co-authored with his wife, Edith Brewster Petrey (1863-1931) and each of their daughters, Helena and Eleanor, served as amanuensis for the project. Helena compiled the index. After the deaths of Herschel and Edith, their daughters donated tons of their papers to St. Elmo City College, of which Herschel had been an original trustee. (This mountain of research survived St. Elmo's many disastrous floods because the Petreys were Midwesterners and their homes-like their lives - had both foundations and attics.) After earning degrees from the University of Nebraska, the Petreys came to St. Elmo at the urging of Methodist friends. Over long careers, the Petreys served St. Elmo's youth as teachers, Edith in the elementary schools, Herschel in the high school: teacher, principal, and eventually President of the Board of Education. A fit, florid man, active in the Temperance Movement and an avowed teetotaler, Mr. Petrey and his family were devout members of the Meth- 
odist church where Edith taught Sunday school and Herschel served on the lay board of deacons. Herschel was also a founder of the Sons of St. Elmo, a beneficent organization of like-minded white men, lampooned by the less lofty as Sonsofbitches of St. Elmo. In addition to all this civic and church service, Petrey toiled for nearly a quarter of a century in history's vineyard. He was obsessed by time and hated clocks.

In History, Heritage and Legacy of St. Elmo (hereinafter HHEL) Petrey attacked the legend of the shipwrecked Jesuit. He noted that the first recorded mention of this valley was in 1773 when Spanish soldiers, searching out deserters, had stumbled on it. The valley's next appearance on record was in 1806 by which time the names St. Elmo and Jesuit Pass seemed already to be in common usage and legal parlance (judging from the earliest court records involving land disputes).

In a particularly astute passage, Mr. Petrey points out:

In 1773 Pope Clement XIV abolished and dissolved the Society of Jesus altogether. ${ }^{*}$ They were not formally reconstituted by the Church until 1814. Thus we can see that there could not possibly have been a Jesuit in California between 1773 and 1806. There could not have been a Jesuit at all. How could a man be a part of something already dissolved?

(HHEL, page 20)

In Herschel Petrey's view, these names, St. Elmo and Jesuit Pass, were but corruptions of Indian language and he had intended to say just that, to call it the Corruption Theory, but Edith demurred. Edith intimated that corruption was rather a strong and slightly briny word trailing a whiff of well, wickedness, a taint of unwholesome miasma, redolent of the grave, the odor of rot, the worm, the spider, and the moth.

His theory appears in the book as Semantic Mishap. Herschel concludes Chapter One thus:

Sober inquiry must lead us away from the fanciful tale of the mad, shipwrecked Jesuit naming an inland area after the patron

*Pope Clement died the next year. Unrelated. (HHEL, footnote, page 20) 
saint of sailors. Semantic Mishap better explains these names. It is my hope that subsequent scholars with time, resources and talents far exceeding my own will uncover the truth, but in all likelihood, that truth will substantiate my conclusions that the simple fact is, the Spanish incorrectly understood the Indians and turned these sounds on the lathe of their own language.

Then, in about 1830 when Mexican sovereignty replaced the Spanish in California, the missionized Indians were dispersed and any possibility of documenting this Semantic Mishap went with them.

There was said to be recorded testimony of the early Indians' encounter with an alleged Jesuit (albeit, even that at third hand). The Catholic Church in the St. Elmo area kept a Book of Asistencias, a sort of hodge-podge of parish activity from 1806 to 1829. Early priests were said to have recorded in these pages several similar accounts of this legend and other fantastic stories that came to them. Unfortunately none of this can be verified, or even investigated as the book has vanished. No one has seen it since the death of Father Nuñez in 1891. Father Nuñez's successor, Father Callahan could not read Spanish and at best offered hearsay evidence as to the actual contents of the Book of Asistencias. * As this history goes to press (1915), the present Catholic pastor in St. Elmo, Father Stoddard, concurs with me that the origins of these names lie in Semantic Mishap, the obscurities of the Indian tongue and the ill-tuned Spanish ear.

(HHEL, page 23)

For Herschel Petrey to so much as mention the Book of Asistencias was a generous gesture, considering his disastrous interview with Father Callahan.

Herschel had planned to take his usual amanuensis, the fair Eleanor, with him to witness and record the interview. Edith quietly vetoed this plan, pointing out that Father Callahan, never minding he was a man of God, had a reputation for, well-let us be candid-drink, and the occasional salty

\footnotetext{
*Father Callahan died in a boating accident off the coast of Mexico in 1902. Unrelated. (HHEL, footnote, page 23)
} 
expression. Need I say more, Herschel? Edith added that she herself preferred not to go with him. This alarmed Herschel as Edith was equal to anything. (Edith had gone with him into the filth and despair, the lightless hovels of Indian homes on all but un-navigable reservations. Later, years later, in 1909, Edith stood with him, watching while Chinatown burned; she brought her notebook and pencil and she dutifully, as befits the historian's helpmeet, recorded the event, though her hand shook and tears ran down her smoke-streaked face. And then, it was Edith who told him not to include this event in his history. Herschel argued that he must, that he was time's servant, history's footman, truth's advocate. Edith said, If you once record what the people of St. Elmo did to the Chinese, allowed to happen to the Chinese, you will tarnish this town forever. Forever, Herschel. Need I say more? Thus it is HHEL, published in 1916, concludes with the year 1908.)

However, to talk with Father Callahan, the Petreys agreed Herschel must have a witness, preferably a teetotaler, a like-minded Methodist and unimpeachably reliable-someone like Wilbur Frett-because, naturally Father Callahan would lie until his teeth fell out. He was a Catholic, wasn't he? Catholics drank and smoked with impunity. Catholics thought they could simply slough off their sins, just slide out of them like a dirty shirt before a Saturday night bath. Confess and be done with it! Effect repentance, forgiveness, redemption of sin with a few mumbled words! Catholics never felt called upon to struggle individually with sin as Protestants must. Methodists especially. Moreover, as a priest, Callahan was absolutely sworn to the triumph of Rome, which would include making a hero out of a mythical Jesuit. Need I say more?

When Seamus Callahan had first arrived in the parish as assistant to the aged Father Nuñez, the local girls had giggled, whispered amongst themselves it was a great pity to waste a man that goodlooking on the priesthood. He had a sallow face, intense gaze, and coarse, curly dark hair, sprinkled now with gray. He seemed, however, always uncomfortable, as though some thorn in his clerical robes nettled, perpetually. He seemed moreover, unsuited to the clergy, neither cheerful and forthcoming like the Methodist pastor, nor bland and efficient like the Mormon elders, nor confident like the Baptists. Callahan was moody, emotional and taciturn; drink intensified these qualities into an indelible melancholy, indigo blue. He had been known to break down and weep at the penultimate moment of the eucharist. He 
conducted the dead out of the world without seeming to feel pity or anything else for them; he baptized babies without so much as a chuck under their fat chins. Given all that, it was an act of some grace and generosity that he should have agreed to discuss the Book of Asistencias with Herschel Petrey, and one can only wonder what Callahan thought when he saw Wilbur Frett in tow, Wilbur, weighted with ink bottles, pens and sheaves of paper.

What Wilbur thought is easier to surmise. He was honored to play caboose to Petrey's mighty engine. Petrey was president of the Board of Education. Wilbur taught shorthand and typewriting at the new Blakely School of Business. Wilbur's features were knotted around his nose and such hair as he had combed from ear to ear over his freckled dome. Mr. Frett's record of this interview is still extant, both the original shorthand transcriptions and the fair copy made from that. Under "witness" is his own signature, a no-nonsense W.F. Frett.

"Know ye by these men present that we, the undersigned, do set our signatures below, and hereby sweareth and deposeth to the truth of this testimony taken in the city of St. Elmo, County of St. Elmo, State of California on this 30th day of August, 1898."

Fr. C-Hot isn't it?

HP-Don't write that down, Wilbur!

The above exchange is then crossed out, but not inked over. (Wilbur's shorthand was as lucid and uncomplicated as his mind.) There were a lot of preliminaries where Father Callahan acknowledges that he is indeed Seamus Callahan, born Sydney, Australia, that he is forty years of age, that his occupation is Catholic priest. The three sat in Father Callahan's study where the curtains were closed against searing afternoon heat. The study (like the Church of the Assumption itself) had a brick-red, impenetrable solidity to it, lest anyone should doubt its permanence or purpose. Father Callahan sat behind his capacious desk, his visitors in deep armchairs set on a Turkey carpet. There were Catholic icons and images on the wall which made Herschel rather uncomfortable, but not nearly so uncomfortable as the doleful ticking of the grandfather clock in the corner. Herschel began to pop sweat before they even began. As Seamus Callahan saw himself as God's servant, so Herschel Petrey saw himself as Time's servant. Neither man was comfortable with his master. Perhaps a servant never is. And never should be. 
HP-Would you please describe the Book of Asistencias?

Fr. C-I have held it in my hand. Often. It was kept right here in this desk. Father Nuñez used to read from it.

HP-But you have not seen it since his death?

Fr. C-No.

HP-What became of the book? Please, don't gesture, Father. It's hard for me to call you Father when you're younger than I.

Fr. C-What difference does it make?

HP-Wilbur can't write down gestures. This is a written record.

The book vanished.

And?

Lost. Gone.

How?

I don't know.

Well-what do you think? Fair means or foul?

Nothing that disappears is fair. It's all foul.

So, Father Callahan, you suspect foul play with this book?

I suspect nothing. I am a believer.

You BELIEVE it disappeared by foul play?

I believe it disappeared.

Are you having a Jesuitical joke with me?

I am not a Jesuit.

Well. Well. The purpose of this inquiry is to discuss the origins of the names of our valley and our historic pass. That's pass, Wilbur, not past.

I know.

People have often wondered how this beautiful inland valley came by its odd nautical name.

I don't think we can get sentimental over the St. Elmo Valley, Mr. Petrey. It's not a place that has ever created anything, nor produced very much. It owes its existence and prosperity to Jesuit Pass. It lies sprawled across the mouth of that pass in a ramshackle, an obscene sort of way. The heat in summer is hellish and the wind-winter and summer-is merciless. Drought is endemic, relieved only by flood. The people are slothful and bigoted. Those who are not slothful are smug, complacent and stultifying. Ugliness and squalor are rampant. Do you mind if I smoke? Can I offer you a cigar?

No. No. No. 
I admit, there are certain spring mornings when you can ride up into the foothills and look at the sheltering mountains and across the valley floor, smell the new grass, the dew drying on the sage, breathe deep, feel whole, even rooted, but hardly sentimental. Would you be wanting a walk in the church garden? It's walled, but there might be a breeze there, some shade. The heat's a killer. A killer, it is.

Wilbur can't record if we're walking. Let us go on. I, that is, my, the-read me my last question, please, Wilbur.

'Are you having a Jesuitical joke with-' That's not what you wanted, Mr. Petrey? Oh. Here. Odd nautical name.

Yes. Let's go back to the Book of Asistencias. Can you describe it?

It was a large volume, folio size, calf bound, the leather shiny from its having been passed through so many hands. The pages were but crudely sewn in, probably by Indian women, but the paper was thick and of good quality and

I mean the contents. Describe the contents. Please.

It was an informal record, parish record, comings and goings, baptisms, marriages, deaths, repairs, accounts and crops. This parish was never so large or grand as the missions along the coast, but there was always a church here and fields cultivated. The Indians built the first irrigation flumes that white men later

I have all that elsewhere, Father Callahan. Here, it's the beginnings, the origins we wish to inquire after.

The book was also used as a commonplace book, that's what Father Nuñez called it, and some of the earliest priests collected stories that seemed to them miraculous or apocryphal, or even simply worth noting.

Like the legend of the shipwrecked Jesuit.

Call it what you like. Contented people have no need of legends.

I have come here today on behalf of history, which also has no need of legends. I am on Time's errand. I am looking for the truth. Why do you scoff, Father Callahan? Surely you believe in the truth.

The truth is like the human body, always being subject to growth and decay. Corruption.

What?

Think of it this way, Mr. Petrey. The truth is the body and history is a suit of clothes. It can be a fine, full silken suit, or tattered rags cobbled 
together, clutched against nakedness because truth never goes about naked. It can't. The truth, unlike the human body, can't be seen in the nude.

What!

It's too terrible. Too too terrible. It must always be clothed and one man's doublet is another man's cowl.

What?

To the man who prefers his truth in a toga, the frock coat of our nineteenth century will look preposterous, but it will nonetheless cover nakedness.

[Wilbur Frett has here inked out several exchanges on the original transcript, inked them out fully. His record continues:]

Fr. C-Very well then, I'll be sticking to the point of your coming here, Mr. Petrey. And the truth of it is, one day the Indians came upon a white man lying on the valley floor. He had no name, but he was from the Society of Jesus. He was alone. He had come from a foreign country far across the sea. He had made a long and dangerous voyage and on that voyage he endured a terrible storm. No-he welcomed that storm, opened his arms to the wind and waves and lightning that battered the ship, tore at the shrouds and sails, lashed at the riggings and beat the halyards mercilessly against the masts. He did not crouch in his cabin, but stalked the deck, praying - not to be delivered from the storm, but to be delivered to the grave. He prayed for a swift, watery death so that his soul would never again want or hunger, but bask in eternal glory. For his body, he cared nothing. Release, that was all he was wanting for his body, deliverance from the unendurable loneliness that had battered his heart and mind for years, the aloneness, the anguish. And then, when it seemed sure that God would, was about to grant his wish to die, fire streaked from heaven, struck the ship, light blazing round the tops of the masts, mad halos, terrible upright torches illuminating the rain, blinding balls of light, light in the midst of darkness, fire in the midst of rain! The belly of the ship split asunder, ripped open by the storm, all hands went down and the ocean's rough blanket wrapped round the wreck.

[Wilbur's pen here stayed too long on the page and there is a big pool of ink which sogged and mottled, softened the paper of the original shorthand transcript. A few drops then hastened to catch up with the account which continues with:]

HP-That was St. Elmo's fire he saw, correct?

There is no St. Elmo. Surely you know that. It's a corruption.

Corruption? 
Of St. Erasmus. St. Elmo is a corruption of language, a bit of bright phosphorescence shining out of decay. St. Erasmus is the patron saint of sailors. One of them.

You mean-are you saying, telling me-there's no St. Elmo?

$\mathrm{Ah}$, but if there were, Mr. Petrey, if there were, for a halo such a saint would wear a crown of flames round his head and perhaps green flames to lick round his feet and he would hold, with impunity-no, more aggressively-like a weapon, his hand clutched round lightning bolts tied up in sheaves, tied with ribbons of smoke. Yes, that would be it, smoke. His symbols would be light and fire and water and he would be the patron saint of illusion. Which, when you think of it, makes him equally, just as much the patron saint of delusion, of disillusion, of dissolution, the dissolute, for all those dissolving in-shipwrecked in their own-Can I-Let me ring for Marta to bring us something to drink. You both look

No. No. Thank you. What, Wilbur? Very well then. Yes. Fine. Ring. Fine. Well, this is all rather discouraging and confusing, ha ha ha. It seems to me ha, ha, that we Protestants have been sadly misled!

That you have, Mr. Petrey, that you

I was speaking metaphorically, humorously suggesting that we, all of us, assumed there was a real St. Elmo.

There is. We're here. This is the church in the real St. Elmo, California. Ah, Marta-lemonade for these gentlemen. Whiskey for me. No soda, but ice. Now, don't be giving me that look, Marta. Ice. Do you think you could find us a bit of ice. I'd be forever in your debt, Marta. Truly.

Getting back then. This Book of Asistencias. Did you read it?

Ah, well, Mr. Petrey, my sainted mother taught me to read English. My granny taught me to read tea leaves. The priests at seminary taught me to read Latin, but I cannot read Spanish.

If you don't know Spanish, you could hardly vouch for

Father Nuñez could read Spanish. He was a Mexican priest. He read to me. He was a humble man, a fine priest. He served God. He served the people of this benighted parish and I

I am here to discuss history, Father Callahan, trying to save the book from

The book is gone. It can't be saved. To be saved you must believe. Now, isn't that so? Even the Methodists - Thank you, Marta. Ah, you found some ice. Bless you. Ice. Lemonade, Wilbur? Mr. Petrey? 
[Wilbur's account is smudged here, presumably from long rivulets of sweat dripping off his icy glass in the breezeless August heat, caged in the priest's study. Wilbur continues with:]

Fr. C-To be saved you must believe and so the book is beyond redemption because you don't believe. You don't believe me. You don't believe Father Nuñez. Perhaps you do not believe that such a book existed, or that it told varying accounts of the same impossible tale, a Jesuit beached here in this valley, a man still dazed and blinded by the fires, the lights at sea, dashed and blown by the storm, all order dissolved, the chaos complete. Think of him, face down on the earth, his clothes wet, caked with mud, seaweed strangled round his wrists and ankles, his skin torn, his beard matted with sand, shipwrecked, alone, beached, cast upon these shores.

But we don't have any shores.

Shut up, Wilbur! Please. I'm sure Father Callahan was speaking metaphorically.

Cast here upon this valley floor, a man who had longed for death, his eyes slowly opening, expecting that he will see the briny lightless ocean floor, the cradle of earth, expecting his bones to be forever rocked in those long long currents, expecting the schools of spangled fish will strip him of his clothes, his very flesh and now, he raises himself up slowly on his arms, blinks as his gaze falls upon an ocean of stubble and sagebrush. He would shake his head, spit salt water and realize he'd misunderstood God's will. He would look into the broad leathery faces of Indians. More lemonade? The Indians also had no names.

When? No lemonade, thank you. When did all this

These people had no names. How can you expect them to have dates?

No names! No dates! Isn't that, really, finally the same thing as saying they did not exist! This is all fanciful and

I'll have some lemonade please, Father Callahan.

[Again the original transcript is splotted and swollen where beads of water have dropped from Wilbur's icy glass. Wilbur continues with:]

HP-In 1773 a party of Spanish soldiers searching for deserters came upon this valley and this pass. Their passage through it was merely incidental, and though they recorded its existence, they did not name it. In 1773 it had no name. We know this from the military records of the garrison in San Diego. There is nothing else until 1806. In 1806 the church 
and the military began keeping records here and we also have the rudiments of a legal system which requires that things be written down. By then, 1806, these names, Jesuit Pass and St. Elmo were already in use. They were used in legal descriptions! How did this happen? Please! Do not merely shrug, drink, smoke and gesture! Speak, Father Callahan, speak! Who wrote these stories down? Where did they come from? Speak! Who had access to this book?

Everyone.

Who? Who!

Many people.

Who!

The dead, Mr. Petrey, the equally nameless, dateless dead. The book was kept here in this office. In this desk, or over there in that bureau. It was not a sacred text.

So it could have been falsified at any time! Many times! Any number of people could have

Why are you here?

Because I am trying to separate fact from fiction! That strikes you as funny, Father Callahan? Funny! I suppose after you drink yet ANOTHER of those, you'll tell me that the Assumption, the Church of the Assumption, this very church was built on the sacred remains of the Jesuit's chapel to Our Lady of St. Elmo.

There was no chapel.

What?

Stay out of this, Wilbur! Now. What? You contradict yourself, Father Callahan.

No. The chapel's just a misunderstanding.

A semantic misunderstanding perhaps?

Perhaps. In the Book of Asistencias, the word was capeeya. That's c-a-p-i-l-l-a. Capilla could be a chapel in the usual sense, a structure with walls and a roof and some permanence and solidity, but more likely by the eighteenth century, the church in California, the Catholic church had discovered what the Jews have long known. You cannot be carrying Chartres on your back.

What? 
If you rely on stones and stained glass, on flying buttresses, high towers and brass bells, your religion will not travel well. You cannot carry vaults and cloisters.

Is that right? C-1-o-y-

Spell it later, Wilbur!

If you intend to explore the undiscovered, your religion must be free of stones and buttresses, permanent structures. You must keep it to words which are portable. You must believe-absolutely-in your power to make holy any place you endow with words and spirit. Like the Jews do with their weddings. They

Please! Father Callahan! We are not here to discuss the Jews!

Capilla might have been a chapel, but not a structure. Perhaps it was a three-sided thatched-brush shelter. Perhaps it was a tumbleweed palace, a towering tumbleweed palace erected over a rabbitskin reliquary, shrouding a flimsy crucifix of spars splintered off from the ship that went down, spars yoked together with seaweed, tied with

Very funny, Father Callahan. Next I suppose

A tumbleweed palace. That all blew away.

In short, you're willing to concede there was no chapel. No Our Lady of St. Elmo. Why do you laugh?

St. Elmo is just a name corrupted into light and fire and all the things you need, but cannot love or hold. A name of light and fire, a miraculous occurrence now pasted on this squalid town full of toadies and humbugs.

Why do you hate St. Elmo so much, Father?

Wilbur-stay out of this!

It is not my country. I have been shipwrecked here. Beached.

Where is your country then, sir?

Wilbur! Please!

I have no country. Oh, I am tired, tired, and it's all

You are drunk, Father Callahan!

Useless and wasted on you, you and everyone like you. You think I lied, that Father Nuñez lied, that the nameless Indians lied, and the anonymous Jesuit lied, that the will of God might not have triumphed over a mere man's killing loneliness, his wish to die, that the will of God might not have triumphed over nature and a storm rise up that would swell those mighty breakers so that they escaped the bondage of the beach and crashed up here, on land, inland, receded, left salt and foam drying on this valley floor along 
with the Jesuit priest. You do not believe that he pulled barnacles from his beard, spit salt water from his lungs and tore at the seaweed binding his wrists and ankles. You don't believe he could have found splintered spars yet clutched tight in his hand, that he made from them a crucifix, an emblem so that he might never forget God's will. You do not believe that he could have named this pass after his order and this valley after God's certain sign-not that he should live or die, but that he should cease quarreling! That he should do God's bidding and not ask for release, or freedom, or death. No, it's wasted on all of you! You will never understand. How can you? You travel in packs! Methodist packs and Masonic processions, Sons of St. Elmo parades, temperance crusades and mobs, regiments of mule drivers and railroad men, and those long, dauntless wagon trains full of Mormons. Hordes of Mormons! Oh God! Hordes of Mormons, always, who distrust solitude of any sort, who cannot even breathe in and out unless there're multitudes all around them! How could they understand? How can any of you? You all live in swarms-in that knit of swarmed connected flesh, flesh like blankets, all tight-woven, warm, stultifying. Children come into the world with pain, out of the loins of people who have coupled without pleasure, people who touch without feeling! How can you understand the passion-the madness, call it what you wish! The illusion, delusion of one who lives celibate and alone and unconnected to humanity, swearing himself to some greater, invisible good, to pluck yourself from the sweet mire of flesh so you can enter God's service, be his servant and find that God hath shipwrecked you on this foreign shore, open your eyes thinking, surely, like pearls, your eyes must roll from their sockets all-seeing, untethered to your head, your eyes roll across the ocean floor, in the black and briny deep, but no! No, the light blinds you and the wind is merciless and God will not let you delude yourself longer. What to do, but call this place after a saint that never was? After an order dissolved, suppressed, abolished. And then - what became of him? Where did he go? Where did he go after that? Where did he die? Who buried him? To die on land, you must, you need someone to bury you. To die at sea, the shroud is already there, cold before you're ever-ever what, empty? The bottle's empty. Ah well, you, Mr. Petrey, you are an unbeliever. You don't believe this Jesuit ever drew breath, of course, so how can you believe he died or care who buried him? 
I'll tell you what I believe, Father Callahan - and my religion, thank you, teaches me to venerate the truth! My profession teaches me to venerate the truth! While yours, your religion and your profession, you practice sophistry. You traffic in superstition. You venerate idols and relics. And you are drunk! That's what I believe! At best, the kindest that could be said of you is that you are an unreliable witness! At worst, I believe you destroyed that book. Yes, I do. After Father Nuñez died. Perhaps before his death. Perhaps the two of you conspired to destroy it. But I am sure that it did not simply vanish. You burnt it. Didn't you?

Petrey, you are a Pharisee and Wilbur, you are a scribe, you are the very people that Christ-in His infinite wisdom-threw out of the temple! You pray in the streets, you slaver after the opinions of men and care nothing for God! You serve two masters! You

Save your invective, Father Callahan. We are leaving. You are an insult to your vocation.

I am human. Do you know what that means? In the singular?

Come on, Wilbur, we

But, Mr. Petrey. We . . . uh, he has to . . . it won't be . . I mean, if he doesn't

Oh. Yes. Very well. Father Callahan, we need you to sign this. Such as it is. Father Callahan! Touch his shoulder, Wilbur. Ask him to

Sign here, Father. Please. Would you? Thank you. Yes. Here's the pen. Sign, please.

Where?

He finished off the ice in their glasses as their footsteps diminished hastily down the passage. The clock ticked slowly in a muffled tenor, chimed the hour in a contralto and the pigeons, protesting the heat, softly counterpointed under the roof tiles. He moved slowly across the room to the water pitcher on the bureau and disturbed the flies. He poured himself a glass of water, then another. The third he poured upon his head, heedless of the Turkey carpet.

Suddenly his eyes lit, as though clearheaded and refreshed, and he shambled back over to the massive desk and rummaged about the drawers, pulling them out, dumping them on the floor and scavenging through their 
miscellaneous contents, working swiftly, glancing up now and then, to be certain no one was watching (at least that no one he could see was watching).

He must have found what he wanted because he stood unsteadily and went to the door, abashed to see Marta there, tray in hand. Her broad, leathery Indian face wrinkled with pity and contempt, which he wordlessly ignored, left her, reeled down the passageway and into the old church garden maintained by Marta's husband, Manuel.

It was unimpressive, walled once with adobe, now red-bricked like the rest of the Church of the Assumption and set about with young crepe myrtle trees, their dry lavender tears scattered on the balding grass. The best-tended part was the kitchen garden, the domestic garden of Manuel and Marta. Neatly staked peppers and tomatoes shone in bright necklaces of red and yellow.

At Manuel's shed, he pulled open the rickety door and stepped inside. He blinked in the dimness and the smell which was oddly, richly rank and vaguely damp. He got hold of a shovel and dragged it over to a crumbling corner, near what was left of the old adobe wall and he began to dig. Sweat ran down his sides and arms and dripped from his upper lip, caught along his eyebrows and clerical collar; his robes grew damp and he panted, but when it was done, it was a fine hole, or at least it would serve its purpose.

He squatted and pulled from his pocket what he had taken from the desk drawer-a motheaten bag of what might once have been fur, but it had fallen out in clumps and now looked only balding and mangy. He opened the bag and threw it in the hole, holding before him what he'd managed to extract, a small, crude, crucifix. It was no bigger than his hand, shards, sharp sticks, hastily tied together with rust-colored material, thicker than yarn, but fragile as paper. Bits of it flaked off in his fingers and drifted, copper-colored motes, into the hole. Tenderly he reached down and placed the crucifix deep down, atop the bag. He stared. He sought some words appropriate to the occasion, but only rutted conventional phrases came to mind, learned phrases. They would not do. So he just muttered, So be it. That's what Marta and Manuel thought they heard as they stood at the gate watching him shovel, filling the hole. Their broad Indian faces were painted with surprise. He finished, coughed and choked as the dust blew in his face and stirred the crepe myrtle blossoms at his feet. He wiped the sweat from his brow and turned, shocked to meet their gaze, amazed as though they 
were great spangled fish swimming toward him over the briny lightless ocean floor. 